\title{
PERAN KETERIKATAN KERJA SEBAGAI MEDIATOR EFIKASI DIRI DALAM MEMPREDIKSI INTENSI KERJA
}

\author{
Kevin Djasa ${ }^{1}$, P. Tommy Y.S. Suyasa ${ }^{2}$, Bonar Hutapea ${ }^{3}$ \\ ${ }^{1}$ Program Studi Psikologi Jenjang Magister, Universitas Tarumanagara, Jakarta \\ Email: kevin.717171019@stu.untar.ac.id \\ ${ }^{2}$ Fakultas Psikologi, Universitas Tarumanagara, Jakarta \\ Email: tommys@fpsi.untar.ac.id \\ ${ }^{3}$ Fakultas Psikologi, Universitas Tarumanagar, Jakarta \\ Email: bonarh@fpsi.untar.ac.id
}

\begin{abstract}
Lecturers are considered important workforce for a university or in any highgrade education institutions. University $X$ had experienced a decrease in educational manpower due to system changes which creates a significant problem towards the university management in fulfilling the needs and demands of lecturers that are needed to accommodate the large ammount of students that are increasing exponentially. To address this problem, the university need to encourage lecturers who had high intentions to quit to be involved more in their professional practices and believe in their skills as a lecturer in the field of teaching, researching and community service. The aim of this research is to understand the role of Work Engagement as a mediator of Self-efficacy in predicting Turnover Intention of lecturers working in a university. This research is an analytic correlational research which uses quantitative approach of Nonexperimental method. Data regarding levels of self-efficacy, work engagement and turnover intention of participants are collected via questionnaire links. The number of participants in this research were 163 lecturers. Self-efficacy and work engagement within the lecturers are categorized as high, besides that turnover intention within the lecturers are categorized as medium. The hypothesis testing used the Spearman Rank with a 95\% trust level. Results show that self efficacy is significant towards turnover intention $(r=-0,408 ; p<0,000)$. Results also show thatself-efficacy is significant towards work engagemen $t(r=0,617$; $p<0,000)$. Work engagement fully mediated the relationship between self-efficacy and turnover intention.
\end{abstract}

Keywords: turnover intention, work engagement, self-efficacy, lecturer, university

\begin{abstract}
ABSTRAK
Dosen merupakan tenaga kerja penting dalam sebuah institusi pendidikan tinggi atau universitas. Universitas $\mathrm{X}$ mengalami penurunan dalam aspek sumber daya dosen akibat pergantian sistem baru sehingga menimbulkan permasalahan bagi pengelolaan universitas dalam memenuhi tuntutan jumlah dosen yang cukup untuk mengakomodasi jumlah mahasiswa yang semakin banyak. Dalam rangka mengatasi masalah tersebut, universitas harus berupaya melibatkan dosen yang memiliki intensi keluar yang tinggi untuk lebih melibatkan mereka dalam praktek profesi dan meningkatkan keyakinan kemampuan mereka dalam mengajar, melakukan penelitian dan pengabdian pada masyarakat. Tujuan penelitian ini adalah untuk mengetahui peran keterikatan kerja sebagai mediator efikasi diri dalam memprediksi intensi kerja pada dosen yang bekerja di universitas. Penelitian ini merupakan penelitian deskriptif analitik korelasi dengan menggunakan pendekatan kuantitatif dengan metode non-experimental. Data tingkat efikasi diri, keterikatan kerja dan intensi kerja responden dikumpulkan dengan link kuesioner. Subyek penelitian berjumlah 163 dosen yang bekerja di Universitas X. Rata-rata tingkat efikasi diri dan keterikatan kerja dosen dalam kategori tinggi, sementara rata-rata tingkat intensi kerja dosen dalam kategori sedang. Uji hipotesis untuk setiap variabel menggunakan Spearman Rank dengan tingkat kepercayaan 95\%. Hasil penelitian menunjukkan terdapat hubungan yang signifikan antara efikasi diri dan intensi kerja $(r=-0,408 ; p<0,000)$. Hasil penelitian juga
\end{abstract}


menunjukkan terdapat hubungan yang signifikan antara efikasi diri dan keterikatan kerja $(r=0,617 ; \mathrm{p}<0,000)$. Keterikatan kerja memiliki peran signifikan sebagai mediator sempurna antara efikasi diri dan intensi kerja.

Kata Kunci: intensi kerja, keterikatan kerja, efikasi diri, dosen, universitas

\section{PENDAHULUAN}

Profesi dosen adalah tenaga pendidik yang bekerja sebagai aset utama pada salah satu institusi pendidikan tinggi yaitu universitas. Universitas merupakan tempat ideal untuk profesi dosen bekerja di mana dosen dapat berkarya dengan menuangkan profesionalitasnya dalam pengajaran, penelitian lapangan, dan memberikan dampak dalam bentuk pelayanan terhadap masyarakat. Undang-Undang Republik Indonesia Nomor 14 tahun 2005 Tentang Guru dan Dosen pada Bab 1 Pasal 1 Nomor 2 menyatakan bahwa dosen merupakan pendidik profesional dan ilmuwan yang memiliki tugas utama mentransformasikan, mengembangkan dan menyebarluaskan ilmu pengetahuan melalui pendidikan, penelitian dan pengabdian kepada masyarakat.

Lembaga pendidikan tinggi yaitu universitas ditugaskan oleh negara untuk mengakomodasi dan menyelenggarakan pengembangan ilmu yang membutuhkan tenaga pendidik dosen untuk bisa mencapainya. Berdasarkan Peraturan Menteri Riset, Teknologi, Dan Pendidikan Tinggi Nomor 2 Tahun 2016 Bab 3 bagian C, sebuah program studi dalam universitas harus memiliki rasio dosen terhadap mahasiswa yang ideal yaitu 1 banding 45 agar dapat melakukan proses pengajaran yang optimal. Sebagai contoh, Universitas X adalah universitas yang memperhatikan dosen sebagai aset utama yang penting dalam pengembangan ilmu pengetahuan dan penelitian.

Universitas $\mathrm{X}$ merupakan salah satu institusi pendidikan tinggi yang memiliki jumlah tenaga pendidik dosen yang banyak dan unit sumberdaya manusia khusus untuk dosen. Semenjak dimulainya kegiatan perkuliahan, Universitas $\mathrm{X}$ telah mengalami peningkatan dalam jumlah penerimaan mahasiswa baru. Pada tahun 2013, universitas menerima lebih dari 3.000 mahasiswa baru. Pada tahun 2016, jumlah mahasiswa lama dan baru yang tercatat dalam Universitas X mencapai 15.000 mahasiswa, ditambah dengan penerimaan mahasiswa baru tahun tersebut yaitu sebanyak 3.990 mahasiswa (Investorid, 2016). Angka tersebut terus meningkat dan memberikan indikasi pada universitas yang seharusnya bisa siap menampung mahasiswa yang memulai studi mereka dan keperluan tenaga dosen yang cukup untuk memfasilitasi dalam aktivitas pembelajaran. Universitas $\mathrm{X}$ mengalami kendala dalam mempertahankan jumlah dosen yang bekerja untuk institusi. Kendala tersebut dirasakan oleh Universitas X semenjak terjadinya pengurangan dalam tingkat sumber daya dosen yang tercatat oleh data Universitas X saat masa transisi pada tahun ajaran 2012/2013 sampai dengan 2014/2015. Tidak mudah untuk sebuah institusi pendidikan tinggi dalam mempertahankan kualitas pengajaran yang baik secara efisien dan konsisten (Figueroa, 2015). Universitas $\mathrm{X}$ mengalami penurunan dalam tenaga pendidik dosen sebanyak $8.44 \%$ selama 4 tahun pengajaran.

Dosen yang bekerja di Universitas X memiliki alasan tertentu pada saat ingin keluar dari pekerjaan mereka atau pindah ke universitas lain. Intensi setiap individu memiliki kesamaan yaitu ingin keluar atau pindah tempat kerja, namun alasan yang menjadi motif dari sebuah intensi bisa berbeda-beda. Universitas $\mathrm{X}$ telah melakukan survei sebelumnya yang bertujuan untuk mengetahui alasan dibalik keinginan para dosen untuk keluar dari Universitas X. Survei dilakukan lewat pengisian data exit interview yang selalu diberikan kepada individu yang sedang dalam 
proses keluar. Data yang dikumpulkan melalui survey menemukan sebanyak $38 \%$ dosen memiliki keinginan untuk berhenti bekerja di universitas dengan alasan ingin mencari gaji dan karir yang lebih baik di tempat lain. Sisanya memiliki alasan seperti keluarga, atasan yang kurang baik dan kurang cocok dengan lingkungan pekerjaan. Ciri-ciri alasan yang dibuat oleh para dosen merupakan cerminan dari sebuah fenomena psikologis yaitu intensi kerja atau intensi keluar kerja.

Intensi kerja adalah intensi untuk keluar atau pindah ke tempat kerja lain, di mana intensi tersebut biasanya berada dalam pemikiran individu yang bekerja dan memiliki alasan spesifik untuk keluar. Penelitian yang dilakukan oleh Bothma dan Roodt menemukan bahwa intensi kerja merupakan indikator yang kuat dalam memprediksi pengunduran diri karyawan (Agoi, 2015). Dampak dari intensi keluar kerja yang tinggi memiliki potensi yang dapat mengganggu jalannya perkuliahan dan kualitas pembelajaran yang ingin diberikan oleh universitas.

Penelitian yang dilakukan oleh Ozyilmaz, Erdogan, dan Karaeminogullari (2018) berusaha untuk menjelaskan konsep bagaimana variabel efikasi diri memiliki hubungan dengan intensi kerja dalam menggunakan kepercayaan organisasi sebagai variabel moderator. Hasil penelitian Ozyilmaz menjelaskan bahwa hubungan antara efikasi diri dan intensi kerja dapat dijelaskan melalui kehadiran variabel kepercayaan organisasi. Mereka menemukan bahwa pada saat kepercayaan organisasi tinggi, maka efikasi diri tidak berperan memprediksi intensi kerja (Crossley, Cooper \& Wernsing, 2013). Namun, pada saat kepercyaan organisasi rendah, maka efikasi diri akan memprediksi intensi kerja. Semakin tinggi efikasi diri, maka semakin tinggi intensi untuk keluar dari pekerjaan. Walaupun Ozyilmaz et al. (2018), telah menemukan bahwa hubungan efikasi diri dan intensi kerja tergantung pada kepercayaan organisasi, namun konsep kepercayaan sebagai moderator tersebut belum sesuai direncanakan oleh Ozyilmaz et al. (2018). Hasil yang tidak sesuai dengan hipotesis penelitian membuka kesempatan bagi peneliti untuk mengajukan konsep pemikiran yang baru. Keperayaan pada organisasi belum bisa membuat hubungan antara efikasi diri dan intensi kerja terpolakan. Penelitian sebelumnya mampu menjelaskan bagaimana sifat pekerjaan yang digunakan dalam penelitian mengakibatkan prediksi yang tidak tepat pada hipotesis yang digunakan (Jain \& Sinha, 2005).

Pada penelitian ini, peneliti bermaksud untuk menguji pengaruh efikasi diri terhadap intensi kerja yang dimediasi oleh keterikatan kerja. Model penelitian diadopsi dari penelitian Kim dan Hyun (2017). Penelitian yang dilakukan oleh Alfes et al. (dalam Bakker \& Albrecht, 2018), menjelaskan bahwa penelitian terkini mengenai hubungan antara efikasi diri sebagai personal resources dan keterikatan kerja membutuhkan penelitian lanjutan yang fokus meneliti dalam konteks atau latar belakang yang berbeda. Penelitian diharapkan dapat memberikan kontribusi teoretis dalam memenuhi literatur mengenai psikologi industri dan organisasi dalam konteks tingkat perguruan tinggi.

Efikasi diri merupakan rasa percaya diri seseorang mengenai kemampuan dan kapabilitasnya untuk bisa memobilisasi motivasi, sumber daya kognitif, dan tahapan tindakan yang dibutuhkan untuk bisa memenuhi tujuan atau permintaan yang situasional. Efikasi diri juga dipengaruhi oleh empat faktor yaitu enactive mastery, vicarious experience, verbal persuasion, dan physiological arousal (Zimmerman, 2000). Variabel efikasi diri dikaitkan dengan variabel terikat yang digunakan dalam penelitian yaitu intensi kerja dimana variabel ini diartikan sebagai sebuah pemikiran yang disadari dan mengacu kepada keinginan individu untuk berhenti dari pekerjaannya 
sehingga pengunduran diri dari pekerjaan bersifat sukarela dari individu sendiri (Robyn, 2012). Efikasi diri diprediksi dapat memberikan pengaruh kepada intensi kerja setiap individu untuk mencegah terjadinya ada intensi pengunduran diri dari pekerjaan. Perusahaan dapat berusaha untuk meningkatkan tingkat rasa percaya diri atas kemampuan setiap karyawan yang bekerja, sehingga pada akhirnya membantu menurukan tingkat intensi kerja karyawan yang ingin mengundurkan diri. Hubungan antara ke dua variabel juga dimediasi oleh variabel keterikatan kerja.

Keterikatan kerja merupakan kondisi positif yang dialami oleh karyawan dalam pekerjaan mereka dan ditunjukkan dengan sifat keterlibatan tenaga kerja dalam melaksanakan tugas mereka. Keterikatan kerja terbagi pada tiga dimensi yaitu vigour, dedication dan absorption (McManus, 2015). Vigour muncul dalam bentuk tenaga dan upaya lebih yang diberikan seseorang dalam mengerjakan tugasnya. Dedication terlihat pada saat seseorang memberikan waktu dan pikirannya kepada pekerjaan yang dilakukan, hal ini terlihat sebagai hal yang bermakna dan signifikan oleh orang tersebut. Absorption merupakan konsentrasi penuh dan rasa tenggelam dalam pekerjaan yang dinikmati oleh individu tersebut (Barkhuizen, 2006). Keterikatan kerja diprediksi dapat membantu memperjelas serta memberikan dampak signifikan pada hubungan antara pengaruh efikasi diri terhadap intensi kerja. Asumsi dasarnya adalah apabila efikasi diri individu memiliki tingkat yang tinggi, maka semakin tinggi pula rasa keterikatan kerja individu pada tempat kerjanya karena individu merasa kemampuannya diperlukan dalam organisasi sehingga semakin rendah pula keinginan dan intensi individu untuk keluar atau pindah tempat kerja. Pengaruh dari efikasi diri dibantu oleh variabel keterikatan kerja dimana variabel tersebut bekerja sebagai mediasi yang meningkatkan kemungkinan hubungan antara kedua variabel terjadi.

Keterikatan kerja digunakan dalam penelitian karena signifikansi variabel dalam memprediksi outcome individu atau secara organisasi sehingga digunakan sebagai mediator dalam penelitian. Keterikatan kerja dalam konteks penelitian ini dapat menjadi predictor yang kuat untuk work outcomes seperti intensi kerja (Memon, Salleh \& Baharom 2017) serta mediator yang menghantarkan hubungan antara efikasi diri dan intensi kerja. Gambaran hubungan antara variabel dapat dilihat pada gambar 1. Pada dasarnya, semakin seorang terlibat dan menempatkan fokus utama kepada pekerjaannya maka semakin rendah intensi orang tersebut untuk berhenti dari pekerjaannya. Pengertian ini juga menyambungkan keterikatan kerja sebagai dorongan atau modal psikologis yang mendorong seseorang untuk bisa lebih terlibat dalam pekerjaan mereka. Komponen keterikatan kerja dalam penelitian ini dilihat sebagai komponen penting yang dapat membantu memperjelas hubungan antara dua variabel penting dan memberikan solusi empiris pada penelitian sebelumnya yang pernah dilakukan oleh Ozyilmaz et al (2018). Semakin menarik dan melibatkan pekerjaan individu, maka semakin sedikit waktu yang dapat digunakan individu dalam memikirkan untuk keluar(Saks dalam Gupta \& Shaheen, 2006). 


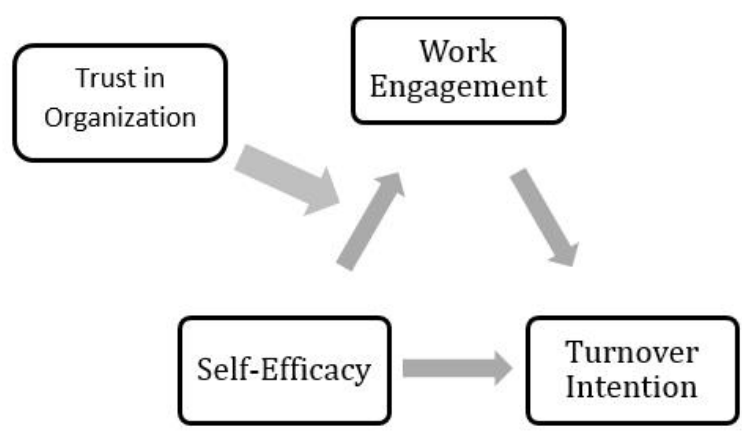

Gambar 1. Gambaran Hubungan Keterikatan Kerja Sebagai Mediator Antara Efikasi Diri \& Intensi Kerja

\section{METODE PENELITIAN}

Penelitian ini merupakan penelitian kuantitatif korelasional. Penelitian kuantitatif korelasional bertujuan untuk menyajikan pengujian hubungan lengkap antara variabel penelitian yang terjadi pada suatu fenomena atau kenyataan sosial. Pengujian dilakukan terhadap variabel efikasi diri, keterikatan kerja dan intensi kerja yang dibentuk dengan tahapan yang jelas dari mendeskripsikan setiap variabel yang bersangkutan dengan masalah yang diteliti sampai pada pengujian hubungan setiap variabel yang berada pada konteks hipotesis yang digunakan.

Penelitian ini dilakukan di Universitas X yang memiliki berbagai cabang di Tangerang, Surabaya, dan Medan. Universitas bergerak pada tingkat pendidikan tinggi. Pertimbangan peneliti memilih universitas tersebut dikarenakan fenomena intensi kerja dan pengunduran diri yang terjadi cukup banyak pada Universitas $\mathrm{X}$ sehingga jumlah dosen aktif dan memiliki status sebagai dosen tetap sampai sekarang diperlukan untuk menggambarkan kondisi Universitas $\mathrm{X}$ yang masih menjalankan kegiatan perkuliahan. Peneliti telah menyebar kuesioner penelitian kepada kelompok dan forum dosen, namun pada batas waktu penelitian yang telah ditentukan ternyata hanya 163 dosen yang mengisi dan mengembalikan kuesioner yang dijawab secara lengkap dengan jumlah 146 dosen yang layak digunakan sebagai data valid untuk diolah oleh peneliti.

Kuesioner yang digunakan dalam penelitian yang dilaksanakan merupakan hasil adaptasi alat ukur dari 3 alat ukur yang digunakan yaitu GSES (General Self-Efficacy Scale), UWES (Utrecht Work Engagement Scale) dan Turnover Intention. Adaptasi dari alat ukur GSES digunakan untuk membantu mengukur variabel efikasi diri pada dosen. Adaptasi alat ukur UWES digunakan untuk membantu mengukur variabel keterikatan kerja pada dosen. Adaptasi dari alat ukur Turnover Intention digunakan untuk membantu peneliti mengukur variabel intensi kerja. Kuesioner pada penelitian dibuat dalam bentuk kuesioner elektronik yaitu dengan menggunakan Googleform.

Instrumen penelitian yang digunakan dalam penelitian untuk bisa mengukur tingkat efikasi diri seorang individu adalah dengan alat ukur GSES (General Self-Efficacy Scale) yang terdiri dari 10 butir pertanyaan dan telah diadaptasi oleh Schwarzer dan Jerusalem pada tahun 1995 (dalam Lönnfjord \& Hagquist., 2018). Instrumen efikasi diri menggunakan metode pengukuran skala Likert yang terdiri dari $1-5$ pilihan jawaban, apabila individu menjawab 1 artinya 'sama sekali tidak yakin' dan menjawab 5 artinya 'sangat yakin' dengan contoh butir sebagai berikut: Seberapa yakin perasaan anda merancang kegiatan atau cara pengajaran baru yang menarik minat para mahasiswa. Pada akhirnya, skor efikasi diri tergambar dari hasil akhir pengukuran instrumen. Nilai reliabilitas instrumen sudah teruji pada penelitian sebelumnya dengan mendapatkan nilai cronbach alpha sebesar 0.937. 
Instrumen penelitian yang digunakan dalam mengukur tingkat keterikatan kerja adalah alat ukur UWES (Utrecht Work Engagement Scale) yang terdiri dari 17 butir pertanyaan yang terbagi dalam tiga dimensi tertentu yaitu vigour (6), dedication (5), dan absorption (6). Instrumen penelitian menggunakan metode pengukuran skala Likert $0-6$ dimana semakin tinggi skor yang didapatkan oleh partisipan yang mengisi instrumen, maka semakin tinggi pula gambaran tingkat keterikatan kerja yang dimiliki oleh individu. Masing-masing peristiwa yang ada dalam setiap butir pertanyaan telah dimodifikasi untuk bisa disesuaikan dengan pembagian dimensi keterikatan kerja. Instrumen penelitian UWES memiliki pengujian reliabilitas yang baik dimana nilai koefisien reliabilitas dan validitas instrumen adalah $0.88-0.95$ dengan contoh butir sesuai dimensi: Saya merasa sangat bersemangat dalam pekerjaan saya di universitas ini (vigour), Saya merasa bahwa pekerjaan yang saya lakukan sebagai dosen memiliki makna dan tujuan (dedication), Waktu terasa berlalu begitu cepat ketika saya sedang bekerja (absorption).

Instrumen yang digunakan untuk mengukur tingkat intensi kerja adalah instrumen skala turnover intention. Alat ukur ini memiliki 5 jumlah butir pertanyaan yang telah diadaptasi oleh Wayne et al. (1997). Instrumen turnover intention menggunakan metode pengukuran skala Likert yang terdiri dari $1-7$ pilihan jawaban, dimana poin 1 artinya sangat tidak setuju dan poin 7 artinya sangat setuju dengan contoh butir: Saya ingin keluar dan mencari pekerjaan di luar Universitas ini. Metode penilaian atau skoring instrumen ini adalah dengan menjumlahkan seluruh skor pada masing-masing butir pertanyaan sehingga akhirnya mendapatkan satu skor total.

\section{HASIL DAN PEMBAHASAN}

Analisis hasil menggunakan bantuan perangkat lunak untuk menghitung serta melakukan kalkulasi statistika antara variabel. Perangkat lunak yang digunakan dalam rangka melaksanakan analisis data adalah melalui aplikasi SPSS dan SmartPLS. Aplikasi SmartPLS digunakan untuk menguji hubungan antara variabel. Matriks korelasi pada penelitian dapat dilihat pada tabel 1 di bawah ini.

Tabel 1. Matriks Korelasi Variabel Penelitian

\begin{tabular}{|c|c|c|c|c|c|c|c|}
\hline & Variabel & $M$ & $S D$ & 1 & & 2 & 3 \\
\hline 1. & Intensi Kerja & 2,96 & 1,50 & - & & & \\
\hline 2. & Efikasi Diri & 3,86 & 0,66 & $\stackrel{-}{0,408^{*}}$ & - & & \\
\hline 3. & $\begin{array}{l}\text { Keterikatan } \\
\text { Kerja }\end{array}$ & 4,44 & 0,79 & - & $0,617 *$ & & \\
\hline
\end{tabular}

Berdasarkan hasil pengolahan data, peneliti memperoleh hasil gambaran setiap variabel penelitian pada dosen yang bekerja di universitas. Intensi kerja pada dosen cenderung memiliki nilai rendah $(M=2,96$ dan $S D=1,50)$ sehingga hasilnya berbeda dengan apa yang didapatkan dalam survei sebelumnya (skala 1 - 7). Selanjutnya, nilai rata-rata efikasi diri pada dosen cenderung memiliki nilai tinggi $(M=3,86$ dan $S D=0,66)$ (skala 1-5). Hasil yang ditemukan mengkonfirmasi dan sejalan model Kim dan Hyun (2017) pada literatur sebelumnya bahwa model tersebut dapat digunakan untuk bisa menemukan hasil korelasi setiap variabel penelitian. 
Hasil pada nilai rata-rata keterikatan kerja dalam penelitian ini cenderung memiliki nilai tinggi ( $M$ $=4,42$ dan $S D=0,78$ ) (skala $0-6$ ). Hasil penemuan tersebut sejalan dengan penelitian Zamralita (2017) yang mengindikasikan bahwa dosen yang bekerja di universitas memiliki tingkat keterikatan kerja yang tinggi. Dosen pada dasarnya melibatkan diri mereka bekerja sebagai dosen dengan menuangkan tenaga, waktu dan perhatian selama bekerja dalam ruang lingkup universitas (Gupta \& Shaheen, 2017).

Untuk menguji hipotesis peneliti menggunakan software PLS untuk melihat peran efikasi diri dan keterikatan kerja terhadap intensi kerja. Tahapan selengkapnya akan dijelaskan dalam Tabel 2 dan 3.

Tabel 2. Hasil Uji Efikasi Diri sebagai Prediktor Intensi Kerja

\begin{tabular}{cccc}
\hline Uji Regresi & Nilai t & Nilai $\beta$ & $\begin{array}{c}\text { Nilai } \\
\mathrm{p}\end{array}$ \\
\hline $\begin{array}{c}\text { Outcome: Intensi } \\
\text { Kerja }\end{array}$ & & & \\
\hline $\begin{array}{c}\text { Predictor: } \text { Efikasi } \\
\text { Diri }\end{array}$ & 5,765 & $-0,408$ & 0,000 \\
\hline
\end{tabular}

Pengujian efikasi diri sebagai prediktor intensi kerja pada dosen di universitas dilakukan dengan menggunakan perangkat lunak SEM-PLS (Structural Equation Modeling - Partial Least Squares). Melalui penghitungan statistik dengan menggunakan PLS, peneliti menemukan bahwa efikasi diri berperan sebagai prediktor intensi kerja $(\beta=-0,408 ; p=0,000<0,05)$. Dengan demikian, hipotesis 1a yang berbunyi terdapat pengaruh signifikan pada efikasi diri terhadap tingkat intensi kerja pada dosen universitas berhasil dibuktikan.

Tabel 3 Hasil Uji Keterikatan Kerja sebagai Mediator antara Efikasi Diri dan Intensi Kerja

\begin{tabular}{cccc}
\hline $\begin{array}{c}\text { Tahapan Uji } \\
\text { Regresi }\end{array}$ & Nilai t & Nilai $\beta$ & Nilai p \\
\hline $\begin{array}{c}\text { Pengujian Tahap } \\
\mathbf{1}\end{array}$ & & & \\
\hline $\begin{array}{c}\text { Outcome: } \\
\text { Keterikatan Kerja }\end{array}$ & & & \\
\hline $\begin{array}{c}\text { Predictor: Efikasi } \\
\text { Diri }\end{array}$ & 14,303 & 0,617 & \\
\hline $\begin{array}{c}\text { Pengujian Tahap } \\
\text { (Tanpa } \\
\text { Mediator) }\end{array}$ & & & \\
\hline $\begin{array}{c}\text { Outcome: } \text { Intensi } \\
\text { Kerja }\end{array}$ & & & \\
\hline $\begin{array}{c}\text { Predictor: } \text { Efikasi } \\
\text { Diri }\end{array}$ & & & \\
\hline $\begin{array}{l}\text { Pengujian Tahap } \\
\mathbf{3} \text { (Dengan } \\
\text { Mediator) }\end{array}$ & 5,765 & & \\
\hline
\end{tabular}




\begin{tabular}{cccc}
\hline $\begin{array}{c}\text { Outcome: } \text { Intensi } \\
\text { Kerja }\end{array}$ & & & \\
\hline $\begin{array}{c}\text { Mediator: } \\
\text { Keterikatan Kerja }\end{array}$ & 3,632 & $-0,424$ & 0,000 \\
\hline $\begin{array}{c}\text { Predictor: } \text { Efikasi } \\
\text { Diri }\end{array}$ & 1,179 & $-0,148$ & 0,222 \\
\hline
\end{tabular}

$\mathrm{t}=$ Nilai uji signifikansi; $\beta=$ Koefisien regresi; $\mathrm{p}=$ Nilai uji signifikansi $\mathrm{p}$

Melalui penghitungan statistik dengan menggunakan PLS, peneliti menemukan bahwa efikasi diri memiliki pengaruh yang signifikan sebagai prediktor keterikatan kerja dosen $(\beta=0,617 ; p=0,000$ $<0,05)$. Dengan demikian, hipotesis $1 \mathrm{~b}$ yang berbunyi terdapat pengaruh signifikan pada efikasi diri terhadap keterikatan kerja pada dosen universitas berhasil dibuktikan.

Prosedur pengujian keterikatan kerja sebagai prediktor intensi kerja dilakukan menggunakan bantuan dari PLS. Berdasarkan penghitungan statistik menggunakan PLS, peneliti menemukan bahwa keterikatan kerja memiliki pengaruh yang signifikan sebagai prediktor intensi kerja dalam dosen. Nilai $(\beta=-0,424 ; p=0,000<0,05)$. Dengan demikian, keterikatan bekerja dosen dalam pekerjaannya memiliki potensi untuk memprediksi dan mempengaruhi intensi ingin keluar dosen sehingga sejalan dengan penemuan Zamralita (2017) \& Kim \& Hyun (2017).

Dalam aspek lain, koefisien regresi $(\beta)$ hubungan antara efikasi diri dan intensi kerja mengalami proses kenaikan pada saat mendapatkan variabel keterikatan kerja sebagai mediator. Nilai koefisien regresi yang pada awal mulanya memiliki nilai rendah $(\beta=-0,408)$ mengalami kenaikan menjadi $(\beta=-0,148)$ pada saat variabel keterikatan kerja hadir menjadi mediator. Hasil penemuan ini mengindikasikan bahwa fungsi keterikatan kerja sebagai mediator antara dua variabel lainnya bersifat menyeluruh dan merupakan mediator yang sempurna. Dengan demikian, hipotesis 2 yang menyatakan terdapat pengaruh mediator yang signifikan pada keterikatan kerja terhadap hubungan antara efikasi diri dan intensi keluar pada dosen universitas berhasil dibuktikan.

\section{KESIMPULAN DAN SARAN}

Berdasarkan hasil penelitian, ada beberapa penemuan dan kesimpulan dalam penelitian ini. Pertama, berdasarkan hasil temuan pada tabel 1, tingkat efikasi diri dan keterikatan kerja pada dosen di universitas tergolong tinggi. Selain itu, tingkat intensi untuk berhenti kerja yang dimiliki oleh dosen di universitas tergolong rendah. Hal ini menunjukkan bahwa dosen merasa yakin dan memiliki keterikatan dengan pekerjaannya sebagai dosen. Dosen yang bekerja di Universitas X juga memiliki intensi untuk keluar dari pekerjaannya walaupun tidak tinggi.

Kedua, berdasarkan hasil uji hipotesis dalam penelitian ini efikasi diri berperan sebagai prediktor dan memiliki korelasi yang signifikan dengan intensi kerja dan keterikatan kerja. Hal ini menunjukkan bahwa tingkat keyakinan diri dosen bisa menjadi acuan yang membantu memprediksi tingkat intensi kerja dan keterikatan kerja dosen.

Ketiga, keterikatan kerja berperan sebagai mediator sempurna antara efikasi diri dan intensi kerja. Artinya, keberadaan keterikatan kerja mampu menjadi perantara antara efikasi diri dan intensi 
kerja, dimana keterikatan kerja dapat menjelaskan hubungan antara dua variabel tersebut. Dengan demikian, keterikatan kerja berperan sebagai mediator sempurna yang berarti seluruh pengaruh efikasi diri terhadap intensi kerja dapat dihantarkan melalui keterikatan kerja dosen.

Berhubungan dengan penelitian selanjutnya yang dapat ditelusuri lebih lanjut mengenai intensi kerja dosen, ada beberapa aspek yang dapat dijadikan sebagai bahan pertimbangan. Pertama pada penelitian selanjutnya dapat memperbanyak jumlah partisipan dosen untuk bisa mengakomodir jumlah data yang masih kurang dengan melibatkan beberapa universitas untuk ikut membantu dalam pengambilan data. Apabila universitas lainnya dapat memberikan jumlah dosen untuk bisa mengisi menjadi partisipan maka diharapkan bahwa penelitian mengenai intensi kerja pada dosen yang bekerja di universitas akan bisa semakin kaya. Memperluas jangkauan dan jumlah partisipan pada penelitian dapat membantu penelitian dalam memberikan data yang bervariasi dan memperkaya data yang didapatkan.

Saran teoretis untuk penelitian berikutnya adalah dengan mempertimbangkan serta melibatkan faktor-faktor atau variabel lainnya yang belum sempat diperhitungkan sebelumnya dalam penelitian yang telah dilaksanakan seperti kepercayaan pada organisasi, tingkat pendidikan, jenis kelamin, dan pendapatan. Berhubungan kebanyakan dari variabel yang digunakan dalam penelitian ini bernuansa internal seperti efikasi diri, intensi kerja dan keterikatan kerja, sangatlah penting untuk peneliti berikutnya mempertimbangkan pengaruh faktor eksternal untuk bisa menjelaskan penelitian dari berbagai sisi. Faktor-faktor yang dimaksud antara lain adalah peran keluarga dan lingkungan pekerjaan dosen di universitas.

Peneliti berikutnya juga dapat melakukan eksplorasi lebih lanjut dalam meneliti variabel personal resources. Eksplorasi mengenai variabel personal resources lainnya selain efikasi diri yang belum sempat dilaksanakan dalam penelitian ini dapat membuka pintu baru dan menjadi pertimbangan untuk dilibatkan dalam penelitian berikutnya apabila peneliti selanjutnya ingin atau tertarik untuk meneliti mengenai efikasi diri dosen yang bekerja di universitas.

\section{Ucapan Terima Kasih}

Ucapan terima kasih peneliti sampaikan kepada seluruh universitas yang telah mengizinkan peneliti untuk melakukan pengambilan data. Khususnya kepada seluruh partisipan yang telah bersedia meluangkan waktu mereka untuk membantu dengan mengisi kuisioner yang diberikan.

\section{DAFTAR PUSTAKA}

Agoi, L. F. (2015). Effect of work engagement on employee turnover intention in public sector, Kenya. International Journal of Economics, Commerce and Management, 3(12), 426-440.

Bakker, A. B., \& Albrecht, S. (2018). Work engagement: Current trends. Career Development International, 23(1), 4-11.

Barkhuizen, N., \& Rothmann, S. (2006). Work engagement of academic staff in South African Higher Education Institutions. Management Dynamics., 15(1), 38 - 46.

Crossley, C. D., Cooper, C. D., \& Wernsing, T. S. (2013). Making things happen through challenging goals: Leader proactivity, trust, and business-unit performance. Journal of Applied Psychology, 98(3), 540. 
Figueroa, O. (2015). The Influences Impacting Staff Turnover in Higher Education. College Professional Studies, Northeastern University.

Gupta, M., \& Shaheen, M. (2017). Impact of work engagement on turnover intention: Moderation by psychological capital in India. Business: Theory and Practice, 18, 136.

Investorid, G. (2016, August 20). Jumlah mahasiswa UPH capai 15.000 orang. Investor.https://investor.id/national/jumlah-mahasiswa-uph-capai-15000-orang

Jain, A. K., \& Sinha, A. K. (2005). General health in organizations: Relative relevance of emotional intelligence, trust, and organizational support. International Journal of Stress Management, 12(3), 257.

Lönnfjord, V., \& Hagquist, C. (2018). The psychometric properties of the Swedish version of the general self-efficacy scale: A Rasch analysis based on adolescent data. Current Psychology, 37(4), 703-715.

McManus, J., \& Mosca, J. (2015). Strategies to build trust and improve employee engagement. International Journal of Management \& Information Systems (IJMIS), 19(1), 37-42.

Memon, M. A., Salleh, R., \& Baharom, M. N. (2017). The mediating role of work engagement between pay satisfaction and turnover intention. International Journal of Economics, Management and Accounting, 25(1), 43-69.

Ozyilmaz, A., Erdogan, B., \& Karaeminogullari, A. (2018). Trust in organization as a moderator of the relationship between self-efficacy and workplace outcomes: A social cognitive theory-based examination. Journal of Occupational and Organizational Psychology, 91(1), 181-204.

Robyn, A. M. (2012). Intention to quit amongst generation Y academics at higher education institutions (Doctoral dissertation, Stellenbosch: Stellenbosch University).

Kim, W. \& Hyun, Y. P. (2017). The impact of personal resources on turnover intention: The mediating effects of work engagement. European Journal of Training and Development, 41(8), 705-721.

Wayne, S. J., Shore, L. M., \& Liden, R. C. (1997). Perceived organizational support and leadermember exchange: A social exchange perspective. Academy of Management Journal, $40(1), 82-111$.

Zamralita, Z. (2017). Gambaran keterikatan kerja pada dosen-tetap ditinjau dari karakteristik personal. Jurnal Muara Ilmu Sosial, Humaniora, dan Seni, 1(1), 338-345.

Zimmerman, B. J. (2000). Self-efficacy: An essential motive to learn. Contemporary educational psychology, 25(1), 82-91. 